April 1999

\title{
Visions of the Good Society and the Religious Roots of American Political Culture
}

Rhys H. Williams

rwilliams7@luc.edu

Follow this and additional works at: https://ecommons.luc.edu/social_justice

Part of the Sociology Commons

\section{Recommended Citation}

Williams, Rhys H., "Visions of the Good Society and the Religious Roots of American Political Culture" (1999). Social Justice. 56.

https://ecommons.luc.edu/social_justice/56

This Article is brought to you for free and open access by the Centers at Loyola eCommons. It has been accepted for inclusion in Social Justice by an authorized administrator of Loyola eCommons. For more information, please contact ecommons@luc.edu. 


\title{
Visions of the Good Society and the Religious Roots of American Political Culture
}

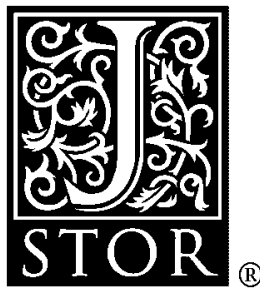

\author{
Rhys H. Williams \\ Sociology of Religion, Vol. 60, No. 1. (Spring, 1999), pp. 1-34.
}

Stable URL:

http://links.jstor.org/sici?sici=1069-4404\%28199921\%2960\%3A1\%3C1\%3AVOTGSA\%3E2.0.CO\%3B2-I

Sociology of Religion is currently published by Association for the Sociology of Religion, Inc..

Your use of the JSTOR archive indicates your acceptance of JSTOR's Terms and Conditions of Use, available at

http://www.jstor.org/about/terms.html. JSTOR's Terms and Conditions of Use provides, in part, that unless you have obtained prior permission, you may not download an entire issue of a journal or multiple copies of articles, and you may use content in the JSTOR archive only for your personal, non-commercial use.

Please contact the publisher regarding any further use of this work. Publisher contact information may be obtained at http://www.jstor.org/journals/asr.html.

Each copy of any part of a JSTOR transmission must contain the same copyright notice that appears on the screen or printed page of such transmission.

The JSTOR Archive is a trusted digital repository providing for long-term preservation and access to leading academic journals and scholarly literature from around the world. The Archive is supported by libraries, scholarly societies, publishers, and foundations. It is an initiative of JSTOR, a not-for-profit organization with a mission to help the scholarly community take advantage of advances in technology. For more information regarding JSTOR, please contact support@jstor.org. 


\title{
Visions of the Good Society and the Religious Roots of American Political Culture
}

\author{
Rhys H. Williams*
}

Southern Illinois University

Seymour Martin Lipset once observed that "Americans are particularly inclined to support movements for the elimination of evil."1 Lipset was making a statement about the style, as well as the substance, of American politics. There is the clear tendency to transform "moral" issues into political issues - and to regard political issues as moral issues; Lipset noted that the dominant political posture in American politics is one of "outraged virtue."

Lipset joins many others in recognizing the extraordinary vibrancy of religion in American culture and one of its particularly visible manifestations - the religiously-based political movement. Any number of movements for social reform in US politics have drawn their resources primarily from religious communities (e.g., Hart 1996; Smith 1996). Social movements have relied on churches for members, money, leadership, communication networks, and local organization. Religio-moral issues, from abolition to temperance to pacificism to gay rights, have dominated a variety of political campaigns (e.g., Gusfield 1963; Hammond 1979; Kleppner 1970; Morris 1984).

In this essay I examine the historical roots of the "cultural resources" (Williams 1995; Kniss 1996) used by a number of social movements. Cultural resources are the symbols, meanings, ideologies, and legitimacy that movements and other political actors use in their collective actions; they function to recruit members, persuade bystanders, and neutralize their opponents. In American politics, cultural resources drawn from religion are particularly potent even if religious groups as such are not prominent players within the movement. Our ideas about politics, even many of our supposedly secular ideas, are rooted in

\footnotetext{
* Direct correspondence to Rhys H. Williams, Department of Sociology, Southern Illinois University, Carbondale, IL 62901-4524, (618) 453-7610, e-mail: willthys@.siu.edu.

Earlier versions of this paper were presented to the 1994 meeting of the Society for the Scientific Study of Religion, Albuquerque, NM and the Chicago Area Group for the Study of Religious Communities, University of IllinoisChicago, April, 1996. I thank Gene Burns, Mark Chaves, Michele Dillon, David Hackett, Laurel Kearns, Fred Kniss, Mary Ellen Koniecrny, Don Robinson, Joe Tamney, and Steve Warner for useful reactions to the earlier drafts.
}

${ }^{1}$ Comments made in an Author-Meets-Critics session on Lipset's book American Exceptionalism: A Double-Edged Sword, (New York: W.W. Norton 1996) at the annual meeting of the American Sociological Association, New York, NY, 1996. 
religion. Specifically for this essay, I argue that the dominant American political ideas about what forms the "good society" are moral visions that were originally religiously-grounded conceptions about human society and its relationship to the divine.

In different terms, I am going to approach religion in American politics from a Geertzian $(1973,1983)$ perspective. Rather than pay attention to the religious attitudes of individuals, or to the organizational involvement of churches, I wish to understand how religious ideas undergird the cultural themes that inform how Americans think and talk about public politics. These religious ideas have become cultural resources that many different groups - not only religiouslybased movements - draw upon for a variety of political uses. As these notions have been decoupled from their original social contexts and social group "carriers," they become increasingly flexible and open to interpretation. Thus the ideas I present here form an "axis of interpretation" in American political rhetoric - something used by many groups but still resonating with a great deal of persuasive power. ${ }^{2}$

\section{EXPLORING PUBLIC DISCOURSE}

The substantive case I use to explore the relations between American religious and political cultures is rhetoric about the "public" or "common" good and the social arrangements that will achieve it. Public good rhetoric is something of a "meta"-theme in political culture, potentially available to any and all groups or movements within American society. There is a universal quality to the ideas. Public good rhetoric is not tied to any particular policy positions, nor is it confined to specific types of issues. Rather, it is the assumptions and assertions about what constitutes the good society that lie behind more specific rhetorical pronouncements. Public good talk remains rhetoric, however, in that it is purposive and is meant to persuade. It may not always be rationally calculated in any formal sense or ideologically manipulated in any cynical sense. But talk about the good society is meant to communicate beyond group or movement members themselves and ostensibly to persuade others. All rhetorical appeals, particularly those calling for change, must strike a balance by drawing upon accepted and easily recognized cultural meanings, but do so in an innovative manner. People must be convinced that something "new" is being offered, but the persuasion must be done within the parameters of recognizable discourse so that the claims will be intelligible. Thus, public rhetoric must be framed in ways that connect to themes in the wider political culture (e.g., Hart 1996; Tarrow 1992; Williams and Williams 1995).

2 I emphasize that I mean "politics" in the broad sense - decision-making about collective life and the authoritative distribution of valued resources. 
An important reason for connecting to the extant culture is to establish political legitimacy; it is a way of claiming a "seat at the table" of public politics. Establishing legitimacy is an inherently moral task - it must combine the reality of politics and power with an authoritative sense of "ought." One way of gaining this credibility is through the "disinterested" moral content of one's rhetoric (see Williams and Demerath 1991). It is here that public good language is so important. It is a fundamentally moral political language; a normative language that is potentially binding on others as well as those who use it. It helps construct a public posture that claims to transcend self-interest and realpolitik, and connects a movement with such moral concepts as selflessness, sacrifice, and above all, "community."

As I have argued elsewhere (Williams 1995) the images and symbolism of "community" resonate deeply in contemporary American culture, across any number of social, religious, and political movements or groups. It is a symbol that can pull together both the internal and external dynamics of group solidarity and movement mobilization - that is, it can serve as an expressive symbol that fosters internal identity and meaning, and it is a potent instrumental symbol used externally to press a movement's case to broader publics.

Thus, there is a paradox confronting actors who attempt to influence the public order: they must advocate something that is simultaneously new and recognizably legitimate. Even if groups stake their claim to public influence by claiming a new vision for the society, they must do so within a language that has shaped the forms that are currently dominant. This is one dimension of "cultural power" (Demerath and Williams 1992). Political actors talk about issues in particular ways because of the shaping power of the existing legitimate ways of framing the debates. These legitimated ways of understanding public life comprise what I call a "cultural repertoire" (Williams 1995, 1996) - a set of boundaries to what is considered legitimate.

Accordingly, there is a repertoire of rhetorical models with which social groups can discuss the public good. Certain understandings of what constitutes the good society have become more or less standardized, legitimate, and diffused throughout the culture. The content of the repertoire shapes the boundaries of what is considered legitimate, and is a powerful factor in influencing the options available to groups as they seek to establish themselves politically. There are several such models - I have found three basic forms - and movements have a certain amount of agency in their capacity to choose among them.

But the "boundaries" on the choices available - the fact that any movement's rhetoric is not created from whole cloth - puts emphasis on historical antecedents and (to push the theatrical metaphor) the attendant scripts. Once a movement commits itself to public rhetoric that is within the logic of a particular culture model in the repertoire, its use has certain implications and ramifications. There is an internal logic to the models, and while movements may combine elements in innovative ways, the models are only incompletely adapt- 


\section{SOCIOLOGY OF RELIGION}

able; they have a range within which they "work." There is a dance between the structuring properties of the rhetorical forms themselves and the innovative agency of practical political actors using them.

My argument proceeds in two steps. In the next section I describe the repertoire of the public good by outlining three ideal typical models of the public good - three visions of the good society. My primary data have been drawn from public accounts of movement activities, and the public rationales presented by movement actors that explain and justify their agendas. In practical terms, this meant scouring the mass media for news accounts of, and interviews with, social movement activists. The secondary sources upon which I draw are those that use as their data public cultural displays. These are "frontstage" presentations of movement rhetoric, meant to reach out to a variety of publics, and based on assumptions about what public rhetoric should be. They are purposive and are meant to persuade.

In the second step of this essay I explore the historical roots of these public good rhetorics. I find significant lineage in various religious ideas about the relationship between humans and the divine, the relations between the individual and the community, and the content of human nature. The history of disestablishment and religious pluralism in the US has produced many sources for contemporary versions of the public good. And, I wish to emphasize, I am not claiming that there is no secular language in American politics. Rather, I demonstrate that the reigning legitimate ways to think about the public good in American political culture are deeply influenced and shaped by America's religious history.

\section{VISIONS OF THE GOOD SOCIETY}

In my examination of the public good rhetoric used by a sample of social movement organizations, I have urcovered three rhetorical models of the public good. ${ }^{3}$ These models are three different ways of talking about the good society and, while often implicit in public rhetoric, they carry different assumptions about societal order, the individual-community relationship, and human nature. I have termed the three rhetorical forms the "covenantal," the "contractual," and the "stewardship" models. I describe each model briefly (fuller descriptions are in Williams 1995).

The covenant model of the public good resonates with the idea of society as a "moral community" in a covenantal relationship with God or some form of transcendent authority. Because the ultimate source of societal authority is beyond the society itself, political reform is often seen as a necessary part of moral reform in accord with transcendent law (Platt and Williams 1988). The common good

31 use the term "models" as Geertz uses the phrase "model for" (1973) - they are prescriptive visions for society appearing in the rhetoric of the users. I am not claiming any formal theoretical status for them. 
is those social arrangements that are in accord with transcendent authority. In the main, individual preferences, wants, and choices are subordinated to the health of the moral community. The community stands before judgment as a collective and thus there is an imperative to confront and repair injustice whether individuals are personally perpetrators or not.

Currently this rhetoric can be found in groups loosely associated with the Christian Right when discussing the "social issues" of contemporary politics (Platt and Williams 1988); for example, Randall Terry's (1988) rationale for the anti-abortion group Operation Rescue is explicit in this regard. However, political conservatism is not inherent in the model. Its defining feature is its reliance on transcendent authority for the ordering of human affairs, not the explicit content of its theology or ethics. Anti-nuclear protest and the Sanctuary movement have both used this rhetoric (e.g., Smith 1996). These movements often focused on "self-abnegation" - the submission of personal interests to duties to a moral community (e.g., Epstein 1991: 195-7, 210-26). Also, many left-liberal proposals for economic reform use a covenantal vision of the good society; in these cases, it is assumed to be individual greed (rather than the New Right's focus on sexuality) that must be controlled for the good of the community (Platt and Williams 1988).

In either the left or right version of the covenant, human nature is not to be trusted and the collective has the moral duty and political right to control individualist impulses. Individualism is easily read as "selfishness" that undermines necessary social solidarity - and in many versions - violates God's will for the community. The inherent depravity of humankind requires the kind of external societal control that political institutions are designed to exert.

The contractual model is a view of the public good built upon ideas of justice and rights, defined as inclusion and participation in society. Expanding from the idea of a society formed through a "social contract," the public good is the creation of an inclusive public through extension of full citizenship, political and economic, to all community members.

American contractual rhetoric springs from aspects of classical liberalism, primarily Locke's notion of citizenship. While the groups eligible for citizenship have varied historically, once a people achieved that status they, as individuals, were fully members of society. There are elements of this "equality within the elect" in the Puritan notion of the community of saints. But as political citizenship was decoupled from one's status in the religious community, equality became more formal, more individualized, and based on a language of rights.

Contemporary concerns with community have led many to criticize classical liberalism for devolving into atomized individualism. Free market models that were first applied to economics, and then politics, have even eroded commitment and solidarity in social life (see, for example, Bellah et al. 1985; Habermas 1989; Glendon 1991; Sandel 1984). The emphasis on the rational pursuit of selfinterest is said to presuppose a selfish conception of human nature; the result is 
an increasingly atomistic society in which all social relations are subordinated to the gratification of the individual. Many commentators claim there is no sense of the public within liberalism (Sullivan 1982).

But there are ways in which that case is overstated. Historically, independence was understood as existing within the context of some form of community; self-reliance was placed within certain societal constraints (Shain 1994; Stout 1988). Liberty from external coercion is central to liberalism but is balanced by the capacity of the individual to make claims upon the polity, and the necessary social relations that implies (Williams and Alexander 1994). While "rights talk" (Glendon 1991) can tend toward the absolute, the universalism in its logic is not necessarily the "slippery slope" into anomic egoism.

Importantly, the contractual worldview proceeds from a tabula rasa understanding of human nature that mitigates the extent to which an atomized individualism degenerates into selfishness. That is, the covenant's assumption about humankind's fallen nature is replaced with the notion of the "blank slate" upon which social forces inscribe individual character. The absence of deformative societal processes allows the individual to develop without the need for externally-derived control of her/his impulses. This trusting conception of human nature holds that oppressive societal arrangements negatively shape individuals' characters. A society that allows for the free and open development of individuals will develop those individuals able to enjoy their autonomy and participate in collective life. The good society becomes just that society that fosters the development and life of fully-realized autonomous individuals.

Assumptions about human nature, and the practical understandings that individuals live within more or less bounded communities, means that the "shared conception" of the public good in the contractual model has changed from the covenant's religiously-based sense of "duty" to the idea of individually held "rights." Society is a set of freely chosen relationships of formal equality. And the only truly authentic forms of community are those marked by voluntarism. This concept of the public good can be found in the rhetoric of many contemporary social movements, particularly those that stress the "natural" rights of marginalized populations to participate fully in societal institutions. For example, the early phase of the civil rights movement emphasized such inclusion-based-on-individual-rights ideas (e.g., S. Burns 1990). Recently, the prochoice movement (Staggenborg 1991) and elements of the gay rights movement (Williams 1995) have all stressed the rights (or entitlements) that append to individuals qua individuals, and the consequent illegitimacy of institutional arrangements that deny individual choice.

Finally, there is a third conception of the public good, the stewardship model, in which contemporary society must manage its resources as much for the future as for the present. This is a common theme in many religious approaches to the world (Fowler 1995a; Hollenbach 1995; Kearns 1990). But what I call the stewardship model is a particular understanding of the good society and is not limited 
to religious organizations, per se. It is a common metaphor for many nonprofit organizations and it is easily found in certain forms of environmentalism.

The stewardship model of the public good and covenant-based formulations of the public good are related through their common focus on "duty," although this is manifested differently. Duty in the stewardship model is thought of as communal, not individual, and the authority to which society is beholden is often less transcendental than natural. The most distinctive differences in the two conceptions can be found in a segment of the environmentalist movement that espouses "deep ecology." Much of the deep ecology discourse is imbued with spiritual significance (Kearns 1996), and often incorporates elements of nonWestern or indigenous American religious systems. Crucially, the perspective stands apart from the predominant traditions in American Christian thinking (see Davis 1991), as the latter have emphasized human dominion over nature and transcendent authority over natural authority. Stewardship rhetoric, as I use the term, is built upon assumptions that are not shared with either the covenantal or contractual rhetorics. That is, the common good is not a religiously-based moral community, nor a society that nurtures individual rights and privileges. It is a community that is harmoniously connected - at both the societal and individual levels - to both its present and its future.

I have offered more detail and more supportive evidence for these three versions of the public good elsewhere (Williams 1995). While they appear in a number of variations in public rhetoric, each has a distinct "center of gravity." The covenant emphasizes the individual's duties to the collective, while contractual thinking focuses on the individual's rights that are protected from communal infringement; in contrast, stewardship rhetoric is a language of collective duties. Due to their level of abstraction, these visions of the good society can be found in the language that surrounds a number of different issues, from abortion to environmental ethics. For example, current debates over immigration to the US show evidence of these same rhetorical models: should the country restrict immigration in the name of preserving the extant community; do immigrants have rights to immigrate; or should the issue be one of environmental impact, resource use, and population density? Despite their varied uses, each of the three languages of the public good has its origins in the US in American religious culture. It is to their origins and developments I now turn.

\section{THE RELIGIOUS ROOTS OF PUBLIC GOOD DISCOURSE}

It is not difficult to see the religious component in some of these cultural languages about the public good. My choice of the label "covenantal" to represent one of the rhetorics is not coincidental. And certain uses of stewardship rhetoric are imbued with a spiritualism that has long been a dimension of American culture. However, these models of the public good, in themselves, are not connected - or at least no longer connected - to any specific religious tra- 
dition. The interweaving of religious and moral traditions within American pluralism has produced distinct rhetorics with overlapping and entwined heritages. The various arguments I discern here often get used in mix-and-match fashion in actual public life; aligning any particular thetorical model with any current faith (or social movement) would reify the categories and oversimplify the positions espoused by many religious and political actors.

However, while these forms of talk about the good society may not be currently connected with specific religious communities, all three models have their roots in sectarian religious thinking. Even contractual arguments, or the leftleaning forms of covenantal rhetoric that share an ideological affinity with socialism, are - in America - desectarianized religious ideas. This section discusses the development and interweaving of ideas about the good society into what I now call the covenantal, contractual, and stewardship rhetorical models.

\section{The Puritan Heritage}

The covenant imagery in American politics comes via the Puritans' identification with the chosen status of the Jews in the Hebrew scriptures. The mission to the new world to build a "New Jerusalem" meant that the sense of chosenness was taken very seriously. However, the covenant's conceptual development is not a single unbroken line of interpretation. Butler (1990) rightly warns against the tendency to see the Puritan experience as overly unified, or overly influential for the nation as a whole. But if one is interested in the development of American political ideas, and not just in our religious pluralism more generally, one can hardly help but devote attention to the Puritans. American religion may not be "Puritanism writ large," but surely American political culture has been profoundly shaped by Puritan ideas about the relations among God, society, and the individual. It is a source of many of the thematic currents that have shaped public talk about the good society.

Of course, the covenant has not gone unchanged from the Massachusetts Bay Colony to the present. Developments within Reformed Protestantism (Butler 1990; Hudson 1987; McLoughlin 1978), waves of new immigrants to North America (including diversity among Anglo-Saxon immigrants, see Fischer 1989), and the shaping character of the frontier on religious life, all worked a variety of meanings into the idea of the covenant. Importantly for the argument here, the covenant contains elements of individualism firmly encased within clear notions of the features of a moral collective. The Puritans' covenantal ideas have been cultural forerunners to both covenantal and contractual models of the public good.

Puritanism in the American colonies envisioned society as a "community of saints." Their endeavor was to be the oft-quoted "city on a hill," a "Holy Community" governed by principles of Christian morality and justice - both a gathering of the elect and a force for reform of the worldly. The organizing principle 
of this community was the covenant, a pact between God and His people that bound each to the other, and gave the human community a transcendent purpose.

Understandings of the nature of the covenant vary. For example, Reichley (1985) has claimed that the Puritans' Covenant was not a contract. A contract is an agreement between equals, like Locke's "social compact;" the covenant was a product of God's will, for His purposes. However, Zaret's (1985) persuasive work on pre-revolutionary Puritanism claims that the covenant was indeed thought of as a "heavenly contract." Zaret claims that the economic imagery was the product of an organizational struggle between laity and clerics for control of Puritanism. The egalitarian implications of the "contract" were obviously attractive to these laypersons, many of whom were in business. Clergy, while stressing the authority themes in the idea of the covenant, were also interested in producing a theology accessible to the laity. Thus contractual elements - and the egalitarian social relations they implied - became a contested part of covenant theology.

Reichley's and Zaret's analyses reveal important - and different - components of the Puritans' Covenant. Zaret studied England, while Reichley focused on the North American colonies; one could reasonably expect to find that covenant theology had differing nuances in different contexts. More significantly, there could be clear differences among the understandings articulated by theologians, the language used by local pastors in the pulpits, and the general interpretations coming from the laity. The production of cultural messages and their subsequent interpretations by listeners are different processes; a single ideational tradition can yield differing fruit.

Walzer (1985) distinguishes between the covenants God made with Noah and Abraham, and that made with the Israelites after the exodus from Egypt. The latter is not an economic contract to be sure, but it is a compact made with a free people. It is not imposed by God, but is a contingent and qualified agreement that required consent on both side. The covenant offered the possibility of freedom, in that it was a freely made promise by individual men and women, but it was also binding on the community. There was the possibility of "doing evil" after the compact, but also the promise of divine punishment - for the entire people of the covenant (1985: 76, 80, 82-3). Thus the exodus covenant is an arrangement that emphasizes responsibility, but also introduces a voluntarism and egalitarianism to God's people.

This voluntarism has particular relevance to American understandings of covenantal theology. Akenson's (1992) study of covenantal politics reveals the extent to which both blood and territory can push understandings of the covenant toward a form of tribalism. He notes the ease with which the covenantal logic that mandates collective responsibility can be reversed so that prosperity becomes evidence for God's blessings (1992: 16). The covenant then legitimates exclusion and even compulsion. 
Akenson's examples of South Africa, Ulster, and Israel are significant, for in each case the covenant is connected to a specific land and divinely-sanctioned claim to it. Further, the claim is made on the basis of the "collective rights" of a people to that land, as guaranteed by God. In the US, despite the language of the "promised land" and the politics of "manifest destiny," a voluntaristic reading of the covenant, and a seemingly wide-open and uninhabited land, has accented the importance of individual consent at the expense of territorialism. Indeed, while covenantal thinking in American political culture emphasizes the duties of the individual to the collective, the counter-theme of individuallybased rights has made the notion of "collective rights" problematic (see Williams and Kubal, forthcoming). Certainly personal and institutional racism supported the exclusion of Native and African Americans from full citizenship. But those social arrangements have been susceptible to arguments based on calls for individual liberty and equal rights. In sum, the evidence for multiple readings of the covenant reinforce my contention that both collectivist and individualist themes were nascent in Puritan culture; both covenantal and contractual rhetorics are deeply rooted in the Puritan contributions to American religious history.

Puritan thought insisted on the total otherness of a transcendent God and the attendant belief that all human institutions were tainted with sin and therefore mutable. Two results sprang from this huge gulf between the human and the divine: first, the covenant was God's will for His people, so only those saved through His unfathomable grace could be included; and second, no human institution (including any political arrangement) was a divine product and all were thus subject to reform. The Holy Community became a gathering of individuals held together by their knowledge of their own salvation. This Community was to work God's will in the world, including purifying social institutions. The Church was not required to save souls, that was the sole province of an awesome Creator and Judge, but to gather the elect and shepherd the Community toward the creation of the New Jerusalem.

As a result, community and individual coexisted in Puritan thought, but coexisted in some tension. The Community was a collection of individuals called to membership, and that calling ensured their election. Within this community of individual "saints," moral egalitarianism was the rule. In practice the Massachusetts colony limited citizenship to members of the Congregational Church, adult white males who had experienced the mystery of "individual spiritual regeneration" (Reichley 1985: 56) - a small percentage of the colony's population. As a result, political elitism and the entitlement to exclude the nonelect from the moral community coexisted with egalitarianism and individualism within the community. However, many scholars (see Reichley 1985; Kelley 1982) note that Massachusetts was not a theocracy. Civil authority was charged with restraining moral and theological deviance, but church elders were not eli- 
gible for positions as civil magistrates and had less direct political power than many clergies in Europe.

In sum, the Puritan covenant was complex. It was a community of individually called saints, morally equal but entitled to exclude the non-elect - yet morally bound to reform all human institutions. The Church and the state were separated and distinct, and yet both were charged with defending and enforcing moral and religious doctrine. God's Community had both the right and duty to conform political action to moral ideals; even if perfection was impossible, progress was mandated. Individual persons had a direct relationship to God and rights granted by God alone, but were subject always to the moral consensus of the gathered elect. These moral and political themes were then filtered through the experiences of settling a frontier society with waves of immigrants, and are clearly still vibrant in contemporary American political thought.

Two developments in pre-Revolutionary Puritanism produced secondary, but noticeable, themes in covenant theology. First were the writings of John Wise who noted that Puritan orthodoxy had failed to prevent the development of a class society. Moral egalitarianism was being threatened by economic and social stratifications. Wise's response was perhaps the first American "populist" solution - the use of the civil government to foster economic and social equality. This meant an expansion of the egalitarianism which "had always existed as a minor chord within Puritanism" (Reichley 1985: 179), from the moral to the socio-economic sphere.

Wise was not advocating change in the conception of the moral community. That change developed, however, as the result of population and economic growth and frontier evangelism (Finke and Stark 1992; Fischer 1989; Innes 1983). Institutions on the frontier did not have the infrastructure to control community or individual life in the same manner as did seaboard society. Added to this was a rising number of merchants and their increasing importance to the colony's economic survival; they chafed under their exclusion from political participation. The "Half-way Covenant" was created, opening church membership, and thus citizenship, to baptized Christians who had not experienced the mystical regeneration. After the 1688 Act of Toleration (for Protestants, of course) the qualification for political citizenship was changed to property ownership rather than church membership.

However, it was Solomon Stoddard and his grandson Jonathan Edwards of what was then the frontier city of Northampton, Massachusetts that incorporated this nascent inclusionary sentiment into Puritan theology. Stoddard believed that the exclusionary Puritanism of the elect would founder on the frontier, where both equality and individualism were accented. He developed a Calvinism designed to reach the masses, making conversion more experiential and less intellectual. Stoddard's theology was not more democratic in terms of the distribution of power, only more popular. "Let the Church include the whole town .. [and then] let God do the selecting" (Reichley 1985: 69). Stoddard jus- 
tified his method with his results, arguing that he was augmenting rather than diluting church membership.

Stoddard was succeeded by Jonathan Edwards. Alarmed at the moral laxity and emotional poverty of the town's religious life, Edwards stressed an experiential religion that still acknowledged God's autonomous grace. He reformulated Puritanism's predestination doctrine to accommodate personal conversion and missionary outreach. Following Stoddard, Edwards continued a series of emotion-filled revivals that established the cultural and organizational foundations for the first "Great Awakening" (usually dated about 1740). Edwards had an even deeper strain of egalitarianism in his thought than Stoddard, using the "perfect brotherhood" of a "happy Christian commonwealth" as his ideal.

While the revivals in the Connecticut River Valley are the best known, the form spread. Not all the attempts at renewal and revival in the 18th century were necessarily based on emotionalism as different traditions and different regions pursued renewal differently (Butler 1990: 177-191; Dolan 1978). But the revival as an organizational form was doctrinally eclectic enough to handle both emotion-filled spontaneity and a recommitment to rational theology and the extant social order.

In this sense, Edwards was a quintessentially American religious figure (Hatch and Stout 1988). He reformulated Calvinism, pushing it away from formalistic academic theology toward experiential faith and more inclusive membership. The combination of rational philosophy and intuitive faith created an "evangelical liberalism." Edwards was committed to the institution of the church and its traditions, and yet his reforms helped set the stage for a thorough democratization of American Protestantism - both spiritually and institutionally.

Where Edwards provided the intellectual underpinnings for Calvinism's efforts at revival, George Whitefield provided its form and social practice. Edwards did not endorse the arminian tendencies of the revivalist religion he was at least partly responsible for formulating (Hudson 1987). He remained convinced that only a combination of head and heart brought authentic faith. Because of that it can be argued that Whitefield was in fact the cutting edge of the changes induced by the "awakening." A mesmerizing preacher, Whitefield travelled, preaching from whatever pulpit he could get himself invited into. Such religious "mixing" and catholicity of spirit began to arouse controversy. By 1744 the doors of Harvard and Yale were closed to Whitefield (Hudson 1987: 72). However, his enthusiastic preaching played well among the populace, setting the precedent for American evangelicalism's signature technology and dominant organizational form - the revival. ${ }^{4}$ Evangelism captured America's frontier culture and brought a principle of inclusion, as well as a measure of economic populism, to Puritanism's conception of the moral community. revivalism.

4 Dolan (1978) demonstrates revivalism's influence as an organizational form by examining Catholic 
These developments toward greater inclusion and egalitarianism may have carried individualistic impulses, but Butler (1990: 179) notes that colonial revivalism often embraced conservative rather than radically egalitarian approaches to authority. Revivalism was often prompted by a concern to redress moral laxity and to increase religious discipline. Certainly the possibility of conversion (and hence salvation) was extended to a wider proportion of the community; and the accent on experience made conversion both more individualized and egalitarian. But these features also show that revivalism was reaffirming the importance of the boundary between the saved and the unregenerate. As conversion became more widely available, those lacking it became even more morally reprobate. The authority of the elect, and their right and duty to exclude others, were affirmed even as revivalism extended the "franchise."

Thus, the prerogatives of the individual were still subordinated to his/her duties to the community and the greater public good. Barry Alan Shain's (1994) study of the Revolutionary era demonstrates that American political discourse elevated the public good over the desires and private rights of individuals. This was true even though Puritan hegemony was long past. Shain describes a more general "reformed Protestant communalism":

[this] traditional Christian view of the just relation between the individual and the community is not individualistic in any modern sense; it is better described as communal, publiccentered, and morally restrictive (Shain 1994: 39).

Significantly, Shain discerns this same public-centeredness even among pietists of the day. Any conception of individual rights that implied the autonomy of the individual from the moral community was inferior to maintaining a moral public sphere, and for political leaders of the day "living without public spirit was equivalent to living without God" (Shain 1994: 40). While the covenant was being expanded and the terms of membership increasingly individualized, the good society continued to subordinate individual wants to collective needs.

\section{Liberal and Individualist Themes}

The stern Calvinism of the reformed tradition clearly emphasized the importance of the collective, and its dour asceticism can easily be interpreted as the antithesis of liberal individualism. Nonetheless, the seeds of the contractual rhetoric of the public good were in the Puritan covenant. The emphasis on individual calling and salvation, the transformation of election from an ascriptive into a more achieved status, and the loosening of church control on the frontier, led to an American individualism that imagined the good society through Protestant lenses. Zaret concludes: "The heavenly contract occupies a central 
place in Puritan divinity because of - not in spite of - the pervasive individualism that is implicated in the idea of contract" (1985: 200).

The major articulation of individualism as the basis for American political culture is Hartz's (1955) recounting of America's "liberal tradition." Hartz maintains that the United States really has but one political tradition, that of liberal pluralist democracy.

[The US is] a society that begins with Locke, and thus transforms him, stays with Locke, by virtue of an absolute and irrational attachment it develops for him, and becomes as indifferent to the challenge of socialism in the later era as it was unfamiliar with the heritage of feudalism in the earlier one. It has within it ... a kind of self-completing mechanism, which insures the universality of the liberal idea (1955:6).

In this view liberalism has a hegemonic place in both American culture and institutions. ${ }^{5}$ The image of America as a "New Jerusalem" made Americans a chosen people and stressed the difference between this nation and Europe's ascriptive society. The US was largely without the established traditional institutions that had dominated feudal and early modern Europe (i.e., the estates, the Church, the patriarchal family). Thus, while in Europe Lockean theory was a defense of the state against these traditional institutions, in the US Lockean theory became a rationale for limiting the state in the interest of "atomistic social freedom" (Hartz 1955: 62). Individualism became unchallenged and was supported by the experiences of frontier and mobility; that is, Locke's understanding of society as originating among contracting individuals in a state of nature seemed less a metaphor than a literal description of the American experience.

Scholars have consistently found liberal individualism in American thought. Even many who criticize Hartz accept the notion of Protestantism's contribution to America's individualist traditions. For example, Roelofs (1992) distinguishes the "Protestant ethos" from the "Bourgeois ethos" not by their relative concern for the commonweal, but whether their fundamental principle is one of spiritual salvation or material acquisition, both viewed individualistically: "at the most profound level, America has no indigenous or autonomous language of the public. ... [O]ur public talk is either derivative from private concerns, or patently, hypocritically superficial" (1992: 42).

The liberal hegemonic thesis has also been argued with evidence from nondoctrinal dimensions of Protestant religious culture. For example, Huntington (1981) describes what he calls the "American creed." It contains core values of American life, mostly centered around ideas of liberty and equality. Huntington claims that periods of "creedal passion" produce political reform movements; further, these political eras follow religious "awakenings" by about two decades. In

5 That Hartz's liberalism contains the assumption of individualism, but is not synonymous with it, is only occasionally recognized (e.g., Shain 1994: 11), but is a point beyond the scope of this essay. 
each successive creedal era, the emphasis on individual liberty and choice is further accented. Similarly, McLoughlin's (1978) theory of revivals and social reform also emphasizes the increasing individualism in American religious culture. He describes four awakenings, each removing individuals from constraining institutions, and stressing the authenticity of unfettered voluntary religiosity. And Hammond (1992) outlines three "disestablishments" of religion, describing each as a further reduction of institutional control of religion. Whether one accepts the story of the progressive individualizing of the Puritan's communal hegemony as a tale of declension (Bender 1978 analyzes this recurring theme), the seeds of contemporary America's "cult of the individual" can be found in the conversionist theology of Puritanism and the nascent bourgeois ethos of Puritanism's primary lay constituency.

In sum, the Puritan legacy is one in which a fear of anarchy led to an intense communalism, even as the fear of tyranny produced protean forms of American individualism. Clearly the religious ideas of the nation's founding periods are multivocal, and provide facilitative directions - rather than determinative channels - for later cultural developments. Both communalism and individualism find their roots in America's Puritan past. And yet, the individualism that marks both contemporary religion as well as politics certainly seems a far cry from the balance of interests over which the Puritans struggled. Even if American individualism had its seeds in Puritan culture, it has grown along different pathways. Where did these individualist developments come from? And conversely, if individualism has so thoroughly decimated our communalist heritage, how has a vision of the moral community remained so vibrant?

\section{Fragmenting the Reformed Hegemony}

A first set of answers is in the changes that swept Protestantism in the early years of the 19th century, particularly in the "burned over district" of upstate New York (Cross 1950) and the southern frontier of western Virginia, Kentucky, and Tennessee. This period is sometimes referred to as the "second great awakening" (Hudson 1987; McLoughlin 1978). ${ }^{6}$

Nathan Hatch (1989) refers to the first quarter of the 19th century as the "democratization" of American Christianity (still overwhelmingly Protestant). He notes that the post-Revolutionary period produced a "crisis of authority in popular culture." Social change contested the relatively fixed character of the colonial social order. Enlightenment and classical republican ideals were being challenged by "vulgar democracy and materialistic individualism," and there were "challenges to any authority that did not spring from volitional allegiance"

6 There is a debate over whether there was an actual increase in the number of revivals, and if so, whether this is evidence for a cyclical theory of revivalism; see the thematic issue of Sociological Analysis volume 44, number 2 (Summer 1983). 
(Hatch 1989: 23). Crises of confidence in established authorities seemed to call for fundamental social reform.

Into this situation came a variety of religious reformers, bringing a type of "religious populism" to a variety of populations. As Jacksonian populism was opening up the political process, so was evangelical religion stretching the boundaries of acceptable religion. Individual voluntarism, popular opinion, and lay-driven organizational structures combined to offer a receptive climate to those groups giving primacy to the individual conscience. Methodism's circuit riders, seldom theologically trained but always "on fire for the Lord," spread a message of salvation available to those who were both socially and geographically marginal. Similarly, Alexander Campbell's Disciples of Christ placed individuals' voluntary acts of commitment at the center of human relations to the divine and salvation. Election became even more a matter of achievement, and less a matter of ascription; conscience became individualized and authority dependent upon voluntarism. Unlike the revivalism of the colonial era, which usually reinforced denominational and clerical institutions (Butler 1990), the changes of the early 19th century changed the nature of religious (and societal) authority.

The dilemma of such a democratization in access to the divine is that the expansion of interpretations is bound to produce some "error." Sola scriptura was an effective doctrine in the battle with upper-class theological elites, but loosely defined it introduced a relativism in doctrine that few Christians of the period were willing to accept. One practical solution to this dilemma was the tight control on interpretation that many sectarian charismatic leaders exhibited. There was a "dichotomy between the rhetoric of people going to the Bible for themselves and the reality of a few strong figures imposing their own will" (Hatch 1989: 183). In addition, most Americans continued to live in small communities with pronounced localist interpretations (Shain 1994). The potential for fragmentation was off-set by the practical parameters of social life and local culture.

But the deep strain of what Peter Williams (1989) calls "anti-structure" in American popular religion made any routinized ecclesiastical authority, including the charismatic domination of sectarian leaders, fragile. The principles of individual conscience and the personalization of religious experience were a consistent source of pressure on all forms of authority. Further, the individualist folk traditions found in Protestantism became augmented by the religious diversity introduced with the arrival of Catholic immigrants. Other religious options, such as a synthetic spiritualism, also accented the religious changes of the period. Combined, these began to produce the types of individualism that we currently recognize in American culture. "The right to think for oneself" (Hatch 1989: 162-189), as a religious principle, has been an enduring legacy of the enthusiastic, popular religious movements of the early 19th century.

Bellah et al. (1985) trace another American cultural principle to the early national-Jacksonian era - the rise of what they term "expressive individualism." 
Expressive individualism is a cultural orientation that elevates the emotional self-fulfillment of individuals as the highest human good. Bellah et al. hold up Walt Whitman as exemplar of that orientation, and also point to its pervasiveness in the assumptions of the contemporary therapeutic culture. Individuals have authentic selves that are repressed by overly controlling societal mores. Only through discovering and understanding the "true" self can one achieve the self-expression necessary for happiness.

Importantly, Bellah et al. argue that the mid-nineteenth century birth of expressive individualism was not a reaction to an overly communalist culture. Rather, expressive individualism was a reaction to the expanding "utilitarian" individualism that was accompanying the national economy's capitalist expansion (1985: 32-35). Emotional release, rather than rational acquisition, was to be the individual's highest calling; the selfishness that seemed to be generated by market behavior could be controlled by the development of what we would now call fully-rounded, healthy individuals. The purpose behind expressive individualism, however, was ultimately self-interested.

Combined with transcendentalism's elevation of the personal spiritual quest, and the impulse to see humankind as a potentially "natural man" in harmony with the environment, expressive individualism offered a way out of the individual vs. community dilemma. The contradiction was side-stepped by locating authority in privatized emotions, and making the good society both a natural outcome of authentic selves and but a way-station on the road to a more universal harmony. This required a view of human nature some distance from the inherent depravity that earned the Puritans' distrust. Even the "blank slate" of classical individualism's homo economicus was inadequate. Expressive individualism could continue to hold a view of the good society as a moral community only if the emotionally-liberated individuals who composed it were fundamentally good. Romantic conceptions of the basic goodness of human nature thus worked simultaneously to support contract thinking while further universalizing the covenant. Putting moral authority within individual selves required that these true selves be released. But release was not license, since the human nature being realized was moral. And since human nature was universal, it was available to all persons on an egalitarian basis.

\section{Catholic Contributions to American Political Culture}

To this point the discussion has focused on Protestant thought, accompanied by the implication of the even stronger claim that American political culture was so thoroughly permeated by Protestantism that it is still impossible to understand the former without an understanding of the latter. And yet, the single largest religious identification in contemporary America is Roman Catholicism. And the United States was significantly transformed in the late 19th, early 20th centuries by the arrival of millions of Catholic immigrants. Of course these 
immigrants and their descendants made a number of adjustments to American society and its Protestant-dominated culture.

Coming to terms with American culture was a challenge for Catholicism, both at the doctrinal level (Burns 1992) and for American Catholics in the pews (Dolan 1992; Appleby 1992). For much of the 19th century the American Catholic church was not a central concern for the Vatican. It was a minority church, less central to its society and to the international church than the churches of either Europe or Latin America. Further, the changes sweeping Europe, Italy in particular, meant that the papacy often had more immediate problems than the American church's relations with its society.

Thus, Rome left much of the task of managing the tensions between Catholic social and political teachings and American political culture to American Catholics themselves, without much in the way of understanding or guidance. Issues such as the creation of national parishes, the use of English, racial integration, even the proposed creation of a Catholic political party (a common vehicle for Catholic interests in Europe) became the center of a debate over the extent to which there would be a distinctively American church. While Protestant nativists often found their fears confirmed by Vatican dicta (both seemed to agree that it was impossible to be both a good Catholic and a true American), the actual positions and practices of American Catholics were often much different.

The challenge of creating a Catholic church in the societal context of the US became known as "Americanism." Americanism was a variant of modern liberal ideology that generally accepted the legitimacy of the separation of church and state and individual freedom of conscience. In contrast, official doctrine reflected the Church's European origins and situation (even as that situation was changing). A state church, with centralized authority over religious life, education, and family law, was still the ideal favored by many (including many in the US; Formicola 1990). For Pope Leo XIII the European experience could be applied fairly unproblematically to the American situation; he claimed that the Church should continue to seek "the favor of the laws and the patronage of the public authority" (quoted in Burns 1992: 81) and in Longinque Oceani (1895) specifically criticized the US's separation of religious and political power (Formicola 1990).

At the same time, the American bishops had to deal with the practical realities of being a minority within a pluralist polity. A state church in the United States would have been thoroughly Protestant, to the detriment of American Catholicism. So American bishops generally avoided political issues and concentrated on building their church, both socially and literally (in the form of sanctuaries, schools, and hospitals). This strategy offered several advantages: it avoided antagonizing Protestant political authorities; it avoided antagonizing Rome by directly repudiating official positions on politics and the state; and it focused energies on nurturing the Church's socially fragile constituencies of 
immigrants, farmers, and the urban working class (Burns 1992). In so doing, the bishops generally accepted the benefits of church-state separation. The "free exercise" and "nonestablishment" clauses of the First Amendment became important supports for their religious autonomy and self-sufficiency. Ironically, Catholics became part of the coalition that favored "liberal" interpretations of church-state separation even as they opposed other aspects of liberalism (Appleby 1992; Burns 1992).

At the same time that Catholics' minority status led to support for political principles emphasizing autonomy from state control of religion, the demands of group preservation meant emphasis on internal communalism and collective identity. This minority solidarity in the face of America's assimilationist tendencies reinforced some Protestant fears of Catholicism's communalism (Bennett 1988). Even as Catholic immigrants were beginning to "make it" in America, a de facto pluralism was developing. Institutional pluralism was manifested most particularly in the creation of Catholic schools to protect children from public schools dominated by Protestant sensibilities (and often direct religious teachings). Social pluralism, in the form of urban "ghettos" and norms of endogamy, preserved Catholic distinctiveness even as American-born generations began to fit into the developing modern economy. And issues of cultural pluralism, such as temperance and Sabbath observance, were the symbolic ammunition of interreligious conflict (Gusfield 1963; Hudson 1987).

The dual process of pluralism and assimilation meant that conceptions of the Church's relationship to society and the individual's relationship to the collective had to be reinterpreted to fit this new historical situation. The controversy over the Church's stance toward society was one that pitted Europeanist views against an Americanist approach (Dolan 1992). The former was a "Christendom" strategy, wherein the Church was seen as the perfect society whose mission was to conquer the world, bringing it under ecclesial control; Church was pitted against, and eventually over, society. The Americanist view, in contrast, saw the Church in society, as an active, interventionist agent attempting to foster godly change; the Church was called to reform society, but by working within it.

It is not coincidental that there are similarities between the Americanist view and what I have called the covenantal approach to the church and worldly institutions. Catholicism's societal collectivism had no chance in the United States; a form of covenantal thinking was the response. But this was not a onesided accommodation - both American Catholic doctrine and the American cultural repertoire of the public good were modified in the process. Many scholars continue to emphasize Protestantism's cultural dominance by claiming that Catholicism (and Judaism) were "Protestantized" by their adaptation to and acceptance in the US (e.g., Kelley 1982; Roelofs 1992). And indeed, the fight for acceptance in America meant that Catholicism had to come to terms with church-state separation and the cultural emphasis on individualism. This was 
the "Americanism" dilemma, and the changes both before and since Vatican II have indeed adjusted Catholic thinking to the dominant themes in American culture.

However, focusing too much on the accommodating done by the Church underplays the extent to which the US was also transformed by Catholic immigrants; this involved an intellectual as well as a social component. Many dimensions of this mutual adjustment, the rise of pluralism, and attendant religious conflict are beyond the scope of this paper. Important here are the contributions Catholicism made to America's cultural repertoire of the public good.

A traditional theme in Catholicism is the image of the Church - and of the well-ordered society - as the "body of Christ." Different "organs" or "appendages" play different roles in the functioning of the whole (McBrien 1982). The whole of the society is the reality, with the various parts or elements having distinct and complementary obligations and contributions to make. The metaphor, of course, appears in Paul's letters and was used by medieval Catholicism as a description of the Church as a "perfect society" (Dulles 1978). It was a society of stability, marked by hierarchy, with an emphasis on the interdependence of obligations. For a medieval society dominated by a translocal church and patriarchal estates, the organic metaphor melded God, His Church, and human society.

The Reformation and Enlightenment thinking challenged this worldview. The official Catholic view of society, and the Church's self-understanding of its place within society, was fundamentally at odds with the assumptions of liberalism (e.g., Hollenbach 1990). In response to these challenges the Church emphasized the institutional dimensions of the organic metaphor, making the church analogous to political society (Dulles 1978; Konieczny 1997). It focused on the governmental and juridical aspects of the church as perfect society, reaching an ideological apex in the First Vatican Council (1869-70). In essence, as liberalism became more of a challenge, the Church further accentuated its ideological differences from it.

While on opposite sides of the Reformation, and with some significant differences, it is nonetheless true that this traditional Catholic notion of the common good had some affinities with the Puritan's covenanted community. It was a substantive notion of the common good, not just a procedural notion that left the content of the good society ultimately undetermined (or a product of the aggregated preferences of individuals). Both Catholic common good and Puritan covenant saw society as a moral community and subordinated individual rights and privileges to that community. Concern with the protection of minorities was muted, and both church and state were charged with the protection of Truth. These similarities provide evidence for the argument that traditional religion of any faith is antithetical to liberalism and liberal society (see examples in Etzioni 1995; Weithman 1997). 
As a social practice, Catholic communalism and covenantal identity have similarities as well. Within the American Catholic experience with national and ethnic parishes, dense social and neighborhood networks developed that resisted racial integration as inimical to "community" (McGreevy 1996). Catholic interracialists tried to use the "mystical body of Christ" theology to promote integration, but the organic metaphor was quite hospitable to conservative interpretations (Konieczny 1997; McGreevy 1996). Similarly, although individualist elements of covenant theology have fostered Protestant liberalism, the idea of the chosen people has been a useful symbolic marker for exclusion.

These parallels aside, there is a decidedly different substantive vision in the content of the Catholic organic body and the Puritan covenant. The hierarchical society of the organic body is some distance from the egalitarianism within the community of saints. There is also a universalism within the traditional Catholic good society that was missing from Puritanism's covenant. The Catholic church held a Truth outside of human creation, but it was potentially open to all, as reason as much as revelation was the tool for coming to terms with this truth. The nonelect in Puritanism were "beyond the pale" and the unregenerate were to be controlled as much as converted or redeemed. Yet one came to the covenant as an individual, and later as a volitional adult, whereas one came to the Church universal through infant baptism - it approached an ascribed rather than an achieved status. Thus, while both were collectivist visions of the good society, their content differed. In each case, the emphasis was on the necessary duties individuals owed to the community to preserve society's connection to the divine. But within Puritanism were elements of what was to become American individualism - a theme some distance from traditional Catholic doctrines.

The nativist antipathy toward Catholicism was multi-dimensional. To many American Protestants, Catholic theology's sacramental emphasis seemed idolatrous and the Church's mediation between the divine and the world sounded suspiciously like magic (McBrien 1982). But the most serious indictment was that Catholicism's principle of communion (as expressed in the Body of Christ image) led to a collectivism that could suppress individuality and eventually freedom of thought (Bennett 1988; Hudson 1987; McBrien 1982). Theological differences were often the articulated expression of social resentments based on cultural identity, political differences, ethnoracial antagonism, and economic competition. Nonetheless, it was the putative threat posed to American democracy and liberty, and their presumed connection to individualism, that lingered as the center of anti-Catholic ideology into the contemporary period.

In fact, Catholicism did add significant resources to collectivist traditions in American thought - even as Catholics themselves worked diligently to prove their patriotism and loyalty. For example, significant elements of the American labor movement were Catholic, and the American bishops, while intensely hostile to socialist or communist doctrine, made periodic statements supporting the 
rights of working people. In part, of course, the American hierarchy's support for labor was a simple response to the needs of its laity - most of whom were working class until the post-war era (and the Church was competing with the labor movement for the loyalties of the working class; see Hartford 1989). Also, Catholics were an important component of Franklin Roosevelt's New Deal coalition, and formed important supportive constituencies for such state-sponsored social welfare policies as Social Security and unemployment compensation.

The central point is that at a fundamental level Catholicism rejected the atomized individualism that developed in 19th century American political culture. A language of obligation and interdependence marked Catholicism's public stance, whether embodied in Bishops' statements or in the practical politics of American Catholics themselves. Indeed, the hostility toward socialism was based as much in socialism's anti-religious content (particularly in Europe) as in its threat to individualism and capitalism (McGreevy 1996). The economic and atheistic dimensions of the communist threat were inseparable to many Americans, but Catholicism harbored ideological themes able to make that distinction.

Such a radical orientation was developed by the social justice thinking of Dorothy Day and the Catholic Worker movement. Beginning in the 1930s and continuing into the 1970s the Catholic Worker stood against militarism, the materialism in American culture, and the wide disparities in wealth created by capitalism. Day repeatedly wrote about the "common good," the need for "community," and even in favor of forms of religious communism (see, for example, Ellsberg 1992: 270-1, 280). In analyzing what she called the "class war" in American society, Day was not doing a Marxian analysis of capitalist economic production, but was rejecting the US's racism, cultural materialism, and its ego-enhancing individualism.

The Catholic Worker's pacificism and racial integrationism led many, particularly political authorities, to question Day's patriotism. And Day herself once wrote a column titled "We Are Un-American; We Are Catholics" (see Ellsberg 1992: 270), bringing to mind the old tensions between nativists and immigrants. However, Day's radicalism had a decidedly American cast to it in its egalitarianism. Her "unamericanism" was not embodied in the hierarchical society of European Catholicism; she rejected all class privileges, even those that were "earned." Importantly, Day did not consider her own material deprivation as a particular vow only for the religious; rather, she called on American society to redistribute its wealth and reject the materialist lure of capitalism. And Day could echo the anti-institutional themes often found in American religion. When the Internal Revenue Service investigated the Catholic Worker in 1972, Day wrote:

[Catholic Worker] refuses to pay taxes, or to 'structure itself' so as to be exempt from taxes. We are afraid of that word 'structure.' We refuse to become a corporation (quoted in Ellsberg 1992: 315). 
By the middle of the 20th century, American Catholics were leaving their ethnic neighborhoods, attending public schools in ever larger numbers, and moving into the middle class. Concomitantly, Catholics were becoming more comfortable with American society socially, culturally, and intellectually. The most significant figure in the intellectual reconciling of Church teachings and American political culture was John Courtney Murray. Murray's project was to establish a way, within Catholic doctrine, to be both Catholic and American (Ferguson 1993; Hunt and Grasso 1992).

In part Murray did so by interpreting the nation's Framers as writing albeit unknowingly - within a "natural law" tradition that was consistent with Catholic thought (Lawler 1992: 117, 119). Further, Murray saw American liberalism as defining liberty in terms of nature and God, rather than the European Jacobin tradition that had no standard for liberty other than "autonomous reason." There is a "truth beyond politics" in the US that, for Murray, brought Catholicism and the "American proposition" into line (Lawler 1992: 126-7).

Moreover, Murray argued that understandings of church-state relations were evolutionary and based in historical and political contingency. This provided room for accommodating Catholicism to its minority status in the US, and helped further the distinction between core doctrine on moral issues and that on sociopolitical issues (Burns 1992, 1996). His reformulations of Leo XIII's churchstate thinking was enough of a challenge to official doctrine and papal authority that he was forbidden to write on the subject for about a decade (Formicola 1990: 37-8). Nonetheless, his "modernizing" of the understanding of the American Church and its relations to the state ultimately became the institutionalized position of the Church - in Rome after Vatican II, but in the practices of American Catholics before that. Murray created a political theology that made it possible to be both Catholic and American.

The changes wrought by the Second Vatican Council moved the Church further toward reconciliation with modern society, particularly in the US. The Council continued its emphasis on the public good, but did so as a moral force within society not as an institution above it. This doctrinal move helped provide the legitimation for the American Church's move into more public politics (Burns 1996; Hanna 1979; Seidler and Meyer 1989). The Church as a whole moved away from a Christendom theology toward a more active acceptance of, and engagement with, the modern world. Such engagement was simultaneously communalist and individualist. Developments in the American Church following Vatican II emphasized greater lay participation in the Church, a greater collegiality within the hierarchy, and a new accent on individual conscience (Burns 1992; Seidler and Meyer 1989).

But the content of the American Church's public stance, especially in the pastoral letters of the National Conference of Catholic Bishops (Hanna 1979; Douglass 1990), has had a developed concern for the collective insurance of social justice. The American Bishops' pastoral letters have emphasized inclusion, 
the moral commonweal, and the destructive characteristics of materialist individualism. When applied to issues of sexual morality and abortion this has been interpreted as "conservative;" when applied to nuclear policy and the economy it has been called "liberal." But in each case the letters have pushed toward a communitarianism that can fit in with American themes of an egalitarian moral community with freedom for the individual conscience (Hollenbach 1990).

Thus, Catholicism has contributed to American ideas of the public good in paradoxical ways. It has contributed a noticeable strain of communalist thinking and practice that has often run counter to both conservative and liberal Protestantism's emphases on the individual. On the other hand, Catholicism has supported several important aspects of religious autonomy from state control and has sometimes found itself in an uneasy alliance with more libertarian positions. This mirrors the American Church's position as an international institution set within a societal context in which its minority status often threatened its survival. Just as elements of both community and individualism can be found in Puritanism, so too can elements of both orientations (differing in their specific content) be found in Roman Catholicism in the US.

\section{NATURE, COMMUNITY, AND THE MINOR THEME IN AMERICAN RELIGION}

While the individual versus community tension is a venerable one in American religion and American political culture, there is a third theme that frames the vision of the good society differently. It is admittedly a minor chord in American culture and has historically waxed and waned. Nonetheless, its presence has offered an alternative set of understandings for those dissatisfied with the cultural answers provided by the major traditions. The key dimension of this religious theme is its emphasis on harmony, conceptualized on a more global scale than is found in the religious cultures examined so far. Because this religious strand is more protean and less institutionalized than the major traditions in American religion it resists easy categorization. In contemporary politics, however, it has emerged as a distinct understanding of the good society. Evidence for aspects of this vision can be found in the "nature religion" described by Albanese (1990), transplanted non-Western religious teachings (Nash 1989), and in certain versions of environmentalism (Ellis 1993; Fowler 1995a; Kearns 1990, 1996).

Albanese's seminal study of "nature religion" in America presents an essential component of the religious theme that focuses on harmony. In sources that range from Native American religious ideas, through the development of transcendentalism, and to contemporary New Age thinking, Albanese finds a spirituality centered on the natural world. She notes that Western religion always had nature as one of its three major concerns - "God, humanity, and nature" (1990: 7); importantly, the nature religion she uncovers does not arrange them 
in a hierarchy, or separate them into distinct spiritual domains. Rather, it merges the three spheres, or at the least emphasizes their interconnectedness.

This interconnectedness means that nature is not, for the most part, put off as distant, divine, and untouchable. Nature religion does involve issues of domination, Albanese observes, but usually in the form of providing resources for humans to live better, longer, and more spiritually whole: "dominance . . . could now be an entirely harmonious enterprise" (1990: 200). Which is not to say that nature religion was or is removed from politics. Phrases such as "natural rights" and "manifest destiny" played on the nation's connection to nature and its land, and the religion of the republic in the early national period had a clearly "politicized rhetoric of nature" (1990: 51). In contemporary politics, Albanese finds the spirit of Green politics (e.g., Davis 1991) imbued with this strand of nature religion, just as Nash (1989) finds a distinct "ethic of nature" within American culture and political ideology.

Images of nature, harmony, spiritual wholeness and the moral innocence that accompanies it, resonate with a deep myth in American political culture that Harrington (1986: 16-7) calls "the myth of deliverance from evil."

At the core of the myth is the conviction that human relations are, by their nature, harmonious, that serious conflict in human societies is unnatural and unnecessary. . . [T] beneath . . . contention, a beneficent natural order within which all interests are complementary. . . . [T] The principles of natural order, if properly understood and followed, resolve conflict without loss to any legitimate interest (emphasis in original).

Elements of this principle of natural order can certainly be found in classical liberalism's assumptions about the "invisible hand of the market" and the ordering of economic interests. Leavened by assumptions about the inherent goodness of human nature found in expressive individualism, this same principle of natural ordering animated many of the counter-cultural ideas of the Sixties; there, elements of "hippie ideology" (if such a term is not oxymoronic) believed that pursuit of individual self-fulfillment and honest desire would produce both happy individuals and harmonious relationships. Similarly, the idea that social conflict results primarily from "miscommunication" or that "education" can improve societal relationships can be found in American pragmatism; witness our commitment to "dialogue" and our preference for dealing with prejudice rather than discrimination.

Another perspective on nature and American religion comes from Kearns's (1990, 1996) systematic study of "eco-theological ethics" among American Christians. She found three streams of thought: Christian stewardship; Ecojustice; and Creation spirituality. These types have some resonance with the three rhetorics I offer here. Christian stewardship, like the covenantal model, is predicated on obedience to a transcendent ordering Will. It attempts a balance between humans' God-given dominion of the world and the need to steward those natural resources that are God's gifts. Eco-justice theology is similar to 
contractual approaches to the public good in its focus on rights and the just distribution of societal resources. In many ways it is a "this-worldly" orientation and is particularly prominent among liberal Protestants (see Fowler 1995a) and Catholics. Finally, what Kearns calls "creation spirituality," like my stewardship model, is concerned with the collective duties humans have to integrate human society with the biosphere. Creation spirituality does not have a conception of the good society, per se, because it rejects such anthrocentrism, but there are clear ideological affinities with my stewardship model of the public good. The writings of Matthew Fox, a former Dominican Brother, form the central texts of this perspective.

While all three of Kearns's ethics are religiously inspired, their religious heritages are not necessarily determinative of their current cultural resonances. Deep ecologists can draw upon ideas from the nation's Christian heritage regarding the sanctity of all creation. Simultaneously, they can muster perspectives from Buddhist thoughts on the sublimation of desire for the achievement of harmony (Nash 1989: 112-118), and Hindu ideas of the sacredness of all life and the cosmic connectedness invoked by concepts such as kharma. This produces a stream of thought with pluralistic resonance and yet is distinct from dominant religious and political discourses (see that repeated emphasis in Davis 1991). For example, Native-American and Hindu conceptions of life and time are often cyclical; life is but one stage in a process that leads away and returns indefinitely. In contrast, the story of the covenant is linear (Akenson 1992; Walzer 1985). The promised land is not returned to, it is achieved. The formation of the covenant itself marks a before-and-after period and creates the history of a particular people.

Nash (1989) explicates a dimension of this difference within environmentalist thought. On one hand, there are what might be termed "liberal" environmental ethics, in which nature must be protected for the good of human society. In contrast is an ethic that endows nature itself with rights that are in principle unabridgeable by human society. Nash (1989: 7) sees in this extension of rights thinking the logical end of liberalism's universal franchise. But he simultaneously recognizes that much of the logic behind the "rights of nature" is different from traditional liberalism. The important symbolic place of the "natural" in American political ontologies (Green 1987 and Rodgers 1987 note the importance of "natural" rights) draws artfully on this ambiguity. While rights language calls on the deeply embedded individualism in our culture, the holistic and cyclical aspects of the "rights of nature" indicate a source of authority distinct from either a sectarian, theistic God, or the atomized individual of American versions of Lockean theory.

Richard Ellis (1993) finds in contemporary environmentalist rhetoric the sole survivor of a classic American religious and political rhetorical form - the jeremiad. A language of "impending catastrophe and future redemption" (1993: 171) calls for a return to a "true" America that is not necessarily rooted in either the historical past or any part of the nation's present. Importantly, Ellis sees in 
this rhetoric that nature is a substitute for God; thus while it is clearly desectarianized (perhaps even "dereligionized"), the spiritual and moral character of the rhetoric's content - and its political functions - remains intact. While I am not certain that radical environmentalism is the sole repository for either the jeremiad or what I am calling stewardship rhetoric, I do agree that those elements can clearly be found there.

\section{PROGRESSIVISM AND THE RISE OF ORGANIZATIONAL SOCIETY}

A particularly important period in the relationship between individualism and community in American culture was the so-called Gilded Age of the late 19th century, and the early years of the "Progressive" era (usually dated 1900. 1914). Enormous cultural and societal changes, such as immigration, industrialization, urban growth, and rising international stature, pushed Americans faceto-face with a new world and simultaneously pushed them to reexamine their cultural resources for interpreting it.

During the Gilded Age period the label "individualist" was the dominant positive description of political positions. Those who wanted to speak affirmatively of a policy or orientation called it individualist. In contrast, "paternalist" was the primary negative label (Green 1987). Even apologists for the great corporations of the industrializing economy described their program as individualist and the corporation itself as a form of the "natural individual" protected by legal rights.

At least in part this was a reaction to the implied "unamerican" character of the new immigrants coming from Europe, who were overwhelmingly Catholic and Jewish. Paternalism was unacceptable as an abridgment of individual rights, an artificial creation of social structures imposed upon individuals possessing the natural rights endowed to them by the Creator. Individualist, in this context, was not a rejection of all authority, but only of that authority connected to "illegitimate" traditional institutions that continued to retard the development of Europe, such as hierarchical religious organizations and class-based social institutions. Contrasted with this was the open mobility - and the nobler moral mission - of the American new world. The irony was that a centralizing economy and an increasingly powerful national state were both interpreted as fostering the conditions for a heightened individualism.

Not everyone was sanguine about the emerging societal order. In particular, the Populist movement of the South and Midwest challenged the developing corporate industrial economy. The cornerstone of the Populist protest was a simultaneous rejection of the incorporation of individuals (particularly small agricultural producers) into increasingly large and impersonal economic organizations, and the heightened individualism and loss of community in American culture (Goodwyn 1978; Williams and Alexander 1994). Significantly, while Populist rhetoric was framed largely in the terms of evangelical 
Protestantism, and in some places succumbed to anti-Catholic nativism, the movement also appealed to many Catholics and liturgical Protestants (Kleppner 1970). The Populists' ideal society, of independent small producers integrally attached to local communities, had elements that appealed to both groups (Williams and Alexander 1994). Importantly, there was a strong emphasis on connections to the land; the sense of the "natural" individual as one connected to agriculture permeated their rhetoric, and weakened the movement's appeal to urban working classes.

By the time Progressivism emerged in the early 20th century, suspicion regarding the growth of the corporate economy was not confined to Populists. Yet the relationship between individualism and the public good of the community was articulated in terms similar to those used in the Gilded Age. As an ideology, Progressivism emerged from a new class of middle-class reformers based in churches, parachurch groups, women's associations, and newly formed graduate divisions of universities (many of them church-related). Progressivism was antiinstitutional in important ways, focusing its attacks on the established order of turn-of-the-century society: monopolistic business corporations; urban ethnic political machines; traditional church hierarchies, and the established political parties. Solutions were sought in political and educational reforms, informed by social science and a civic "religion of America" (Eisenach 1994) that fostered faith in democracy, as conceived by professional and managerial reformers. The extent to which Progressivism revealed the nervousness with which even liberal Protestants were viewing a changing America is shown in the attempts at deracinating the new immigrants (e.g., Hull House) and the emphasis on public schools as the fundamental institutions of the American democratic system.

Progressivism merged traditional national-millennial themes of creating the Kingdom of God on Earth with a social evolutionist perspective on "progress" (Eisenach 1994; Handy 1984). It was a "theology of the fulfillment of America as a historic nation" (Eisenach 1994: 66) wherein democracy became a national faith, undergirded by a social ethic drawn from a new covenant based on public theology. That theology was overwhelmingly drawn from Protestant sources, although it also contained the concerns for social justice and workers' conditions articulated by Catholic elements of the labor movement.

Progressives sponsored numerous ecumenical religious organizations (such as the Federal Council of Churches of Christ founded in 1908) as a demonstration of both their commitment to liberal individualism, and their concern with maintaining a national organizational presence to combat the "illegitimate" organizational power of political parties, urban machines, and traditional churches. Thus, Progressivism was both a secularization of Protestant theology as well as a sacralization of sociology and public philosophy (Fox 1993; Lasch 1990). It was an indirect conquest of public discourse (Green 1987) by a merger of modernized Protestant evangelical theology and the new social sciences. Fox concludes: "The central paradoxes that historians have noted in Progressivism - its moral- 
ism and secularism, its top-down managerialism and faith in popular democracy - are also found in liberal Protestantism" (1993: 640).

Progressivism combined two strategies of social change. The first, "social reconstruction" through institutional reform, had been favored by the Reformed Protestant traditions that created the voluntary associations of American civil society (Hall 1982). These groups saw the creation of non-state voluntary organizations as part of a religious duty. These associations were designed to offer moral individuals the appropriate vehicles with which to engage in social activism; they were non-coercive associations of the like-minded moral elect, entitled to exclude and reform the unregenerate for their own good. The second strategy was the "conversionist" approach to social change that developed out of the revivalist methods of the early 19th century. Institutions were to be changed by the efforts of right-minded individuals, so changing the "hearts and minds" through conversion to exemplary lives was the first step.

However, in order to be sure such converted individuals were in fact rightminded, national and hegemonic sources of democratic and egalitarian thinking had to be promoted. Once again, the vision of the good society that emerged from Progressivism uneasily combined a version of individualism with an accent on communal obligations and Protestant hegemony. In the name of individual liberty, one set of supra-individual institutions were supported at the expense of another set. The extent to which Progressivism was actually facilitating the 20th century's "organizational society" was clouded by the use of individualist and conversionist language to discuss its agenda.

\section{CONCLUSION}

Rhetoric that envisions the public good and an ideal society is an important resource for actors in American politics. Claiming to desire and act for the public good distances actors from charges of self-interest and provides grounding for more specific issue positions. In each version of the public good presented here, the aim for a better community forms the central component of the ideological package. "Community" is a social reality that, whatever its geographical or structural basis, is constructed symbolically (Anderson 1991; Cohen 1985; Fowler 1995b). It is often something claimed by social movements themselves, sometimes as a support for other instrumental aims (Williams and Alexander 1994) and sometimes as an expressive end in-and-of-itself (Epstein 1991; Williams 1995).

The ambiguity of the symbolic construct of the good society is one of its strengths, as it provides a resiliency across historical periods, collective actors, and various issues (e.g., Madsen 1991). Also, the elasticity of the shared meanings attached to the public good have drawn from America's pluralistic past, often giving many marginalized social groups a foothold into the nation's public life. Further, the history of a weak centralized state in the United States, and the 
development of a powerful anti-state rhetoric, have made the call for "community" one with appeal to both collectivists and moderate individualists (Ellis 1993: 163).

The rhetorical models of the public good I present here are not historically unaltered with fixed arrays of meaning; this essay is premised on historical change. But there is a central internal logic to each of these rhetorics that, while variously interpreted, continues to provide a distinct center of gravity. The logic of the different discourses helps structure the ideas and issue-positions available to all groups in society, but the differing logics hide underneath the shared symbol of the public good. While contemporary rhetoric often claims to speak to a unity, it is in fact absent. Contrary to Hartz's (1955) vision of liberalism's hegemony: "Political conflict in the United States has been and continues to be animated by fundamentally different visions of the good life" (Ellis 1993: 151). Our political discourse has been unable to articulate this conflict, or the alternatives proposed by its competing positions, clearly. The rhetorical models draw upon similar histories and in that sense often have deep affinities within the same religious traditions, but their adaptation by and presentation in contemporary politics highlight their differences.

The models I present here are often implicit in public rhetoric but are, I believe, part of the Gordonian knot of contemporary politics. Everyone is for the public good, but what that means, or more accurately whose vision of the public good is predominant, is very much contested. And because the imagery of the common good is so resonant, so intuitively appealing and so implicit, the implications of these differences are rarely addressed directly. A putative source of unity in American political culture - a belief in the common good - is also a great source of contest and struggle.

\section{REFERENCES}

Akenson, D. H. 1992. God's peoples: Covenant and land in South Africa, Israel, and Ulster. Ithaca, NY: Cornell University Press.

Albanese, C. L. 1990. Nature religion in American history: From the Algonkian Indians to the New Age. Chicago, IL: University of Chicago Press.

Anderson, B. 1991. Imagined communities: Reflections on the origin and spread of nationalism. Revised ed. London: Verso.

Appleby, R. S. 1992. Church and age unite! The modernist impulse in American Catholicism. Notre Dame, IN: University of Notre Dame Press.

Bailyn, B. 1967. The ideological origins of the American revolution Cambridge, MA: Harvard Belknap Press.

Bellah, R., R. Madsen, W. Sullivan, A. Swidler, and S. Tipton. 1985. Habits of the heart. Berkeley: University of California Press.

Bender, T. 1978. Community and social change in America. Baltimore, MD: Johns Hopkins University Press.

Bennett, D. H. 1988. The party of fear. Chapel Hill: University of North Carolina Press. 
Burns, G. 1992. Frontiers of Catholicism. Berkeley: University of California Press.

. 1996. Studying the political culture of American Catholicism. Sociology of Religion 57: 37 53.

Burns, S. 1990. Social movements of the 1960s. Boston, MA: Twayne.

Butler, J. 1990. Awash in a sea of faith: Christianizing the American people. Cambridge, MA: Harvard University Press.

Cohen, A. P. 1985. The symbolic construction of community. London: Tavistock Publishers.

Cross, W. R. 1950. The bumed-over district. Ithaca, NY: Comell University Press.

Davis, J., ed. 1991. The EarthFirst! reader. Salt Lake City, UT: Gibbs-Smith Publishers.

Demerath, N. J. III, and R. H. Williams. 1992. A bridging of faiths: Religion and politics in a New England city. Princeton, NJ: Princeton University Press.

Dolan, J. P. 1978. Catholic revivalism: The American experience, 1830-1900. Notre Dame, IN: University of Notre Dame Press.

1992. The American Catholic experience: A history from colonial times to the present. Notre Dame, IN: University of Notre Dame Press.

Douglass, R. B. 1990. The search for a new public voice in American Catholicism: Reason and revelation in the pastoral letter on the economy. In Church polity and American politics: Issues in contemporary American Catholicism, edited by M. Segers, 81-97. New York: Garland.

Dulles, A. 1978. Models of the church. Garden City, NJ: Image Books.

Eisenach, E. J. 1994. The lost promise of progressivism. Lawrence: University of Kansas Press.

Ellis, R. J. 1993. American political cultures. New York: Oxford University Press.

Ellsberg, R., ed. 1992. Dorothy Day, selected writings. Maryknoll, NY: Orbis.

Epstein, B. 1991. Political protest and cultural revolution: Nonviolent direct action in the 1970s and 1980s. Berkeley: University of California Press.

Etzioni, A., ed. 1995. New communitarian thinking. Charlottesville: University Press of Virginia.

Ferguson, T. P. 1993. Catholic and American: The political theology of John Courtney Murray. Kansas City, MO: Sheed and Ward.

Finke, R., and R. Stark. 1992. The churching of America: 1776-1990. New Brunswick, NJ: Rutgers University Press.

Fischer, D. H. 1989. Albion's seed: Four British folkways in America. New York: Oxford University Press.

Formicola, J. R. 1990. American Catholic political theology. In Church polity and American politics: Issues in contemporary American Catholicism, edited by M. Segers, 31-50. New York: Garland.

Fowler, R. B. 1995a. The greening of Protestant thought. Chapel Hill: University of North Carolina Press.

- 1995b. Community: Reflections on definition. In New communitarian thinking, edited by A. Etzioni, 88-95. Charlottesville: University Press of Virginia.

Fox, R. W. 1993. The culture of liberal Protestant progressivism. Joumal of Interdisciplinary History 23: 639-660.

Gamson, W. A. 1992. Talking politics. New York: Cambridge University Press.

Garroutte, E. M. 1992. When scientists saw ghosts and why they stopped: American spiritualism in history. In Vocabularies of public life, edited by R. Wuthnow, 57-84. London: Routledge.

Geertz, C. 1973. The interpretation of cultures. New York: Basic Books.

1983. Local knowledge. New York: Basic Books.

Glendon, M. 1991. Rights talk: The impoverishment of political discourse. New York: The Free Press.

Goodwyn, L. 1978. The populist moment. Oxford: Oxford University Press.

Green, D. 1987. The language of politics in America. Ithaca, NY: Cornell University Press.

Green, J., J. Guth, C. Smidt, and L. Kellstedt. 1996. Religion and the culture wars. Landam, MD: Rowman and Littlefield.

Gusfield, J. 1963. Symbolic crusade: Status politics and the American Temperance Movement. Urbana: University of Illinois Press. 
Habermas, J. [1962] 1989. The structural transformation of the public sphere. Trans. by T. Burger. Cambridge, MA: M.I.T. Press.

Hall, P. D. 1982. The organization of American culture, 1700-1900. New York: New York University Press.

Hammond, J. 1979. The politics of benevolence: Revival religion and voting behavior. Norwood, NJ: Ablex.

Handy, R. T. 1984. A Christian America: Protestant hopes and historical realities. 2nd ed. New York: Oxford University Press.

Hanna, M. 1979. Catholics and American politics. Cambridge, MA: Harvard University Press.

Harrington, M. 1986. The dream of deliverance in American politics. New York: A.A. Knopf.

Hart, S. 1996. The cultural dimension of social movements: A theoretical reassessment and literature review. Sociology of Religion 57: 87-100.

Hartford, W. 1989. Working people of Holyoke. New Brunswick, NJ: Rutgers University Press.

Hartz, L. 1955. The liberal tradition in America. New York: Harcourt, Brace, and World.

Hatch, N. 1989. The democratization of American Christianity. New Haven, CT: Yale University Press.

Hatch, N. and H. Stout, eds. 1988. Jonathan Edwards and the American experience. New York: Oxford University Press.

Hollenbach, D. 1990. Liberalism, communitarianism, and the Bishops' pastoral letter on the economy. In Church polity and American politics: Issues in contemporary American Catholicism, edited by M. Segers, 99-118. New York: Garland.

- 1995. Virtue, the common good, and democracy. In New communitarian thinking, edited by A. Etzioni, 143-153. Charlottesville, VA: University Press of Virginia.

Hudson, W. 1987. Religion in America. 4th ed. New York: Macmillan.

Hunt, R. P., and K. L. Grasso, eds. 1992. John Courtney Murray and the American civil conversation. Grand Rapids, MI: Eerdmans.

Huntington, S. P. 1981. American politics: The promise of disharmony. Cambridge, MA: Harvard Belknap Press.

Innes, S. 1983. Labor in a new land. Princeton, NJ: Princeton University Press.

Kearns, L. 1990. Redeeming the earth: Eco-theological ethics for saving the earth. Paper presented to the Association for the Sociology of Religion, Washington, D.C.

1996. Saving the creation: Christian environmentalism in the United States. Sociology of Religion 57: 55-70

Kelley, G. A. 1982. Faith, freedom, and disenchantment: Politics and the American religious consciousness. Daedalus 111: 127-148.

Kertzer, D. 1988. Ritual, politics, and power. New Haven, CT: Yale University Press.

Kleppner, P. 1970. The cross of culture. New York: The Free Press.

Kniss, F. 1996. Ideas and symbols as resources in intrareligious conflict: The case of American Mennonites. Sociology of Religion 57: 7-23.

Konieczny, M. E. 1997. Collective identities and the contrasting interpretations of an organic metaphor: Specialized Catholic action, Father Coughlin, and the mystical body of Christ. M.A. Thesis, Department of Sociology, University of Chicago.

Kubal, T. 1998. The Presentation of political self: Culture, mobilization, and the construction of collective action frames. The Sociological Quarterly 39:4.

Lasch, C. 1991. Religious contributions to social movements: Walter Rauschenbusch, the Social Gospel, and its critics. Journal of Religious Ethics 18: 7-25.

Lawler, P. A. 1992. Murray's articulation of the American proposition. In John Courtney Murray and the American civil conversation, edited by R. Hunt and K. Grasso, 116-134. Grand Rapids, MI: Eerdmans.

Licbman, R. and R. Wuthnow, eds. 1983. The New Christian Right. New York: Aldine. 
MacPherson, C. B. 1962. The political theory of possessive individualism. Oxford: Oxford University Press.

Madsen, R. 1991. Contentless consensus: The political discourse of a segmented society. In America at century's end, edited by A. Wolfe, 440-460. Berkeley: University of California Press.

McBrien, R. P. 1982. Roman Catholicism: E pluribus unum. Daedalus 111: 73-83.

McGreevy, J. T. 1996. Parish boundaries: The Catholic encounter with race in the twentieth-century urban north. Chicago, IL: University of Chicago Press.

McLoughlin, W. 1978. Revivals, awakenings, and reform: An essay on religion and social change in America, 1607-1977. Chicago, IL: University of Chicago Press.

Morris, A. 1984. The origins of the Civil Rights movement. New York: The Free Press.

Nash, R. 1989. The rights of nature: A history of environmental ethics. Madison: University of Wisconsin Press.

Platt, G. M., and R.H. Williams. 1988. Religion, ideology, and electoral politics. Society 25: 38-45.

Reichley, A. J. 1985. Religion in American public life. Washington, D.C.: Brookings Institution.

Rodgers, D. 1987. Contested truths: Keywords in American politics since independence. New York: Basic Books.

Roelofs, H. M. 1992. The poverty of American politics. Philadelphia, PA: Temple University Press.

Sandel, M., ed. 1984. Liberalism and its critics. New York: New York University Press.

Seidler, J., and K. Meyer. 1989. Conflict and change in the Catholic church. New Brunswick, NJ: Rutgers University Press.

Shain, B. A. 1994. The myth of American individualism. Princeton, NJ: Princeton University Press.

Smith, C., ed. 1996. Disruptive religion: The force of faith in social movement activism. London: Routledge.

Staggenborg, S. 1991. The pro-choice movement. New York: Oxford University Press.

Stout, J. 1988. Liberal society and the languages of morals. In Community in America, edited by C. Reynolds and R. Norman, 127-146. Berkeley: University of California Press.

Sullivan, W. 1982. Reconstructing public philosophy. Berkeley: University of California Press.

Tarrow, S. 1992. Mentalities, political cultures, and collective action frames: Constructing meanings through action. In Frontiers in social movement theory, edited by A. Morris and C. Mueller, 174-202. New Haven, CT: Yale University Press.

1994. Power in movement. New York: Cambridge University Press.

Terry, R. 1988. Operation Rescue. Springdale, PA: Whitaker House.

Wald, K. D. 1997. Religion and politics in the United States. 3rd ed. Washington, D.C.: Congressional Quarterly Press.

Walzer, M. 1985. Exodus and revolution. New York: Basic Books.

Weithman, P. J., ed. 1997. Religion and contemporary liberalism. Notre Dame, IN: University of Notre Dame Press.

Williams, G. I., and R. H. Williams. 1995. "All we want is equality": Rhetorical framing in the Father's Rights movement. In Images of issues, 2nd ed., edited by J. Best, 197-212. New York: Aldine de Gruyter.

Williams, P. W. 1989. Popular religion in America: Symbolic change and the modemization process in historical perspective. Urbana: University of Illinois Press.

Williams, R. H. 1994. Movement dynamics and social change: Transforming fundamentalist ideology and organizations. In Accounting for fundamentalisms: The dynamic character of movements, edited by M. Marty and R.S. Appleby, 785-833. Chicago, IL: University of Chicago Press.

1995. Constructing the public good: Social movements and cultural resources. Social Problems 42 124-144.

1996. Politics, religion, and the analysis of culture. Theory and Society 25: 883-900. 


\section{SOCIOLOGY OF RELIGION}

forthcoming. Public religion and hegemony: Contesting the language of the common good. In The Power of religious publics: Staking claims in American society, edited by W. Swatos and J. Wellman. Westport, CT: Praeger.

Williams, R. H., and S. M. Alexander. 1994. Religious rhetoric in American populism: Civil religion as movement ideology. Joumal for the Scientific Study of Religion 33: 1-15.

Williams, R. H., and N. J. Demerath III. 1991. Religion and political process in an American city. American Sociological Review 56: 417-431.

Zald, M., and J. McCarthy. 1987. Social movements in an organizational society. New Brunswick, NJ: Transaction Books.

Zaret, D. 1985. The heavenly contract: Ideology and organization in pre-revolutionary Puritanism. Chicago, IL: University of Chicago Press. 